\title{
Comparative study on bacterial carbon sources in lake sediments: the role of methanotrophy
}

\author{
K. Steger ${ }^{1}$, K. Premke ${ }^{2,3}$, C. Gudasz ${ }^{1}$, H. T. S. Boschker ${ }^{4}$, L. J. Tranvik ${ }^{1, *}$ \\ ${ }^{1}$ Department of Ecology and Genetics / Limnology, Evolutionary Biology Centre, Uppsala University, Norbyvägen 18 D, \\ 75236 Uppsala, Sweden \\ ${ }^{2}$ Leibniz Institute of Freshwater Ecology and Inland Fisheries (IGB), Müggelseedamm 301, 12587 Berlin, Germany \\ ${ }^{3}$ Leibniz Centre for Agricultural Landscape Research (ZALF), Eberswalderstr. 84, 15374 Müncheberg, Germany \\ ${ }^{4}$ Marine Microbiology, Royal Netherlands Institute for Sea Research (NIOZ), Korringaweg 7, 4401 NT Yerseke, The Netherlands
}

\begin{abstract}
Methane-derived carbon can be important in both benthic and pelagic food webs. Either generated in the anaerobic layers of the sediment or in the anaerobic hypolimnion of stratified eutrophic lakes, methane is an excellent carbon source for aerobic methanotrophic bacteria. The very negative methane $\delta^{13} \mathrm{C}$-signal in the methanotrophic biomass provides an excellent opportunity to trace the use of methane-derived carbon in food webs. We studied carbon sources of benthic bacteria in a range of Swedish lakes with different inputs of terrestrial organic carbon and indigenous primary production. We analyzed the ${ }^{13} \mathrm{C}:{ }^{12} \mathrm{C}$ ratios in phospholipid-derived fatty acids, which serve as biomarkers for specific groups of Bacteria. We demonstrate that methane is an important carbon source for sediment bacteria, not only for the methanotrophic community but also for the non-methanotrophic heterotrophic bacteria. This most likely indirect utilization of isotopically highly depleted methane masks the stable isotope signatures for terrestrial input and local primary production in the heterotrophic bacterial community.
\end{abstract}

KEY WORDS: Benthic microbes $\cdot$ Boreal lakes $\cdot$ Methanotrophic bacteria $\cdot$ Phospholipid-derived fatty acid $\cdot$ PLFA $\cdot$ Stable isotopes

\section{INTRODUCTION}

Lakes commonly import large amounts of terrestrial organic matter, often primarily in the form of dissolved organic carbon (DOC), which is mineralized by bacteria and other biota (Tranvik 1988, Jones 1992). This causes lakes to become heterotrophic (del Giorgio et al. 1999, Cole et al. 2000, Jonsson et al. 2003), resulting in substantial net emissions of carbon dioxide (Cole et al. 1994, Sobek et al. 2003, Battin et al. 2009) and methane (Bastviken et al. 2011) to the atmosphere. The terrestrial inputs can be seen as an energy subsidy to the lake food web (Jansson et al. 2007). Lakes also vary strongly in local primary production mainly caused by differences in nutrient

\footnotetext{
${ }^{*}$ Corresponding author: lars.tranvik@ebc.uu.se
}

availability. A strong contrast can be found between oligotrophic, high-DOC lakes where carbon cycling is driven by external terrestrial inputs versus eutrophic, low-DOC lakes driven by internal carbon cycling, with most lakes ranging in between these extremes. Most studies on external subsidies in lakes have focused on the pelagic carbon cycle (Kritzberg et al. 2004, Pace et al. 2004). However, although a substantial amount of the terrestrial organic matter reaches the sediments, largely via flocculation of DOC (von Wachenfeldt \& Tranvik 2008), the importance of local primary production versus external terrestrial organic carbon sources for the sedimentary carbon cycle has thus far received little attention (Steger et al. 2011).

() The authors 2015. Open Access under Creative Commons by Attribution Licence. Use, distribution and reproduction are unrestricted. Authors and original publication must be credited. 
Methane-derived carbon can be important in both benthic (Grey et al. 2004, Jones \& Grey 2011) and pelagic food webs (Bastviken et al. 2003). Most of these studies examined the stable isotope ratios in animals, and therefore, the carbon source used by these organisms, but only few studies focused on the ${ }^{13} \mathrm{C}:{ }^{12} \mathrm{C}$ ratios in microorganisms (Boschker et al. 1999, Boschker et al. 2005). Methane that is generated in the anaerobic layers of the sediment and in the anaerobic hypolimnion of stratified eutrophic lakes is an excellent carbon source for aerobic methanotrophic bacteria (Kiyashko et al. 2001, Bastviken et al. 2003). The known aerobic methanotrophic bacteria can be classified based on their membrane fatty acids, where type I typically contains 16-carbon and type II comprises 18-carbon fatty acids (Bowman et al. 1991, Tunlid \& White 1992, Bodelier et al. 2009). Type I methanotrophs tend to prevail in the sediment of lakes and build their biomass directly from methane (Hanson \& Hanson 1996). The very negative methane $\delta^{13} \mathrm{C}$ signal in the methanotrophic biomass (biogenic methane -50 to $-110 \%$; Whiticar 1999 ) provides an excellent opportunity to trace the use of methanederived carbon in food webs. In many lakes, benthic macrofauna, such as chironomid larvae, depend to a large extent on methane-derived carbon, probably due to the grazing on methanotrophic bacterial biomass (Jones \& Grey 2004, Eller et al. 2005, Premke et al. 2010).

We investigated the carbon sources of benthic bacteria in a range of Swedish boreal lakes with different inputs from local primary production and from terrestrial organic carbon. Carbon sources utilized by sediment bacteria were studied by analyzing the ${ }^{13} \mathrm{C}:{ }^{12} \mathrm{C}$ ratios in phospholipid-derived fatty acids (PLFAs), which serve as biomarkers for specific groups of Bacteria. We demonstrate that methane-derived carbon is an important carbon source for the hetero- trophic bacteria in lake sediments, thereby masking the stable isotope signatures of terrestrial input and local primary production.

\section{MATERIALS AND METHODS}

\section{Sampling}

Sediment samples were taken from 8 boreal lakes in south-central Sweden during summer and winter of 2007. The lakes were ice-covered for approximately 3 mo (ice break appeared between late March and early April); some of the lakes were thermally stratified during summer and ranged in maximum depth from 3 to $17 \mathrm{~m}$ (Table 1). We collected sediment samples in undisturbed sediment cores (inner diameter: $60 \mathrm{~mm}$; tube length: $60 \mathrm{~cm}$; Uwitec) from profundal and littoral stations (always taken outside the belt of emergent vegetation). Three replicates were taken at each site. Subsamples $(5 \mathrm{ml})$ of the upper $5 \mathrm{~cm}$ of sediment were taken with a syringe for PLFA analysis, well-mixed and kept on ice and in the dark during transport to the laboratory. The samples were stored at $-20^{\circ} \mathrm{C}$ prior to PLFA analysis.

\section{Water chemistry}

Subsurface water samples were taken with a Ruttner sampler of each lake for measurement of total phosphorus (TP) and DOC. Sample water was collected in acid-rinsed $(10 \% \mathrm{HCl})$ plastic scintillation vials $(20 \mathrm{ml})$ for TP and centrifugation tubes $(50 \mathrm{ml})$ for DOC analysis. TP was measured on samples ignited at $550^{\circ} \mathrm{C}$ as molybdate reactive phosphorus according to an established method (Murphy \& Riley 1962),

Table 1. Characteristics of the 8 investigated lakes in Sweden during summer sampling. Sampled depth in the profundal zone is equal to the maximum lake depth. Microbial biomass (MB) represents the sum of all detected phospholipid-derived fatty acids in the profundal (Prof) and littoral (Lit). DOC: dissolved organic carbon, TP: total phosphorus, dw: dry weight

\begin{tabular}{|c|c|c|c|c|c|c|c|c|}
\hline \multirow[t]{2}{*}{ Lake } & \multicolumn{2}{|c|}{ Coordinates } & \multirow{2}{*}{$\begin{array}{l}\text { Lake area } \\
\qquad\left(\mathrm{km}^{2}\right)\end{array}$} & \multirow{2}{*}{$\begin{array}{l}\text { Lake depth } \\
\text { (m) }\end{array}$} & \multirow{2}{*}{$\begin{array}{c}\text { DOC } \\
\left(\mathrm{mg} \mathrm{l}^{-1}\right)\end{array}$} & \multirow{2}{*}{$\begin{array}{c}\mathrm{TP} \\
\left(\mu \mathrm{g} \mathrm{l}^{-1}\right)\end{array}$} & \multicolumn{2}{|c|}{$\mathrm{MB}\left(\mathrm{nmol} \mathrm{g} \mathrm{g}^{-1} \mathrm{dw}\right)$} \\
\hline & $\mathrm{N}$ & E & & & & & Prof & Lit \\
\hline Ljustjärn & $59^{\circ} 55^{\prime}$ & $15^{\circ} 26^{\prime}$ & 0.12 & 11 & 10.3 & 11.7 & 2781.6 & 143.6 \\
\hline Lilla Sångaren & $59^{\circ} 54^{\prime}$ & $15^{\circ} 23^{\prime}$ & 0.24 & 17 & 6.8 & 13.3 & 1074.9 & 221.8 \\
\hline Lötsjön & $59^{\circ} 52^{\prime}$ & $17^{\circ} 56^{\prime}$ & 0.63 & 10 & 12.0 & 39.7 & 3592.8 & 2014.4 \\
\hline Valloxen & $59^{\circ} 44^{\prime}$ & $17^{\circ} 49^{\prime}$ & 2.90 & 6 & 17.6 & 49.7 & 5415.7 & 155.2 \\
\hline Oppsveten & $60^{\circ} 00^{\prime}$ & $15^{\circ} 25^{\prime}$ & 0.65 & 10 & 21.9 & 15.9 & 1219.3 & 615.4 \\
\hline Strandsjön & $59^{\circ} 52^{\prime}$ & $17^{\circ} 10^{\prime}$ & 1.30 & 3 & 21.0 & 38.9 & 2270.8 & 2737.1 \\
\hline Svartjärn & $59^{\circ} 53^{\prime}$ & $15^{\circ} 15^{\prime}$ & 0.07 & 7 & 31.9 & 20.8 & 964.8 & 2692.6 \\
\hline Fälaren & $60^{\circ} 20^{\prime}$ & $17^{\circ} 45^{\prime}$ & 2.05 & 3 & 34.9 & 29.1 & 2816.8 & 3254.0 \\
\hline
\end{tabular}


and DOC concentrations were measured with a Sievers 900 TOC analyzer (GE Analytical Instruments).

\section{Fatty acid analysis}

For the PLFA extraction, the sediment samples were freeze-dried, and between 0.1 and $2.7 \mathrm{~g}$ (higher amounts for sandy littoral samples) of dry weight were extracted with a modified 1-phase Bligh/Dyer method (Frostegård et al. 1991). Lipids were separated into neutral, glyco-, and phospholipids using solid phase extraction with silicic acid columns (BondElut ${ }^{\circledR}$ LRC-Si, Varian). The polar fraction containing the phospholipids was collected, and the fatty acid 19:0 (nonadecanoic acid) was added to the samples as an internal standard. The samples were subjected to a mild alkaline methanolysis for conversion to fatty acid methyl esters (FAMEs) for analysis by gas chromatography (GC). The PLFA samples were dried and stored at $-20^{\circ} \mathrm{C}$.

The quantification and identification of FAMEs was performed on GC as described previously (Steger et al. 2011). In addition, dimethyl disulfide derivatization for identification and quantification of monounsaturated fatty acids followed previous procedures (Steger et al. 2003). Standard nomenclature was used to refer to the PLFAs, and based on the concentrations of 43 individual PLFAs, the total microbial biomass was calculated (Steger et al. 2011).

The stable carbon isotopic composition of the individual PLFAs was determined on a Thermo Delta Plus type of gas chromatograph-isotope ratio mass spectrometer (GC-IRMS). Samples were injected in split-less mode on an HP-5 (60 m, $0.32 \mathrm{~mm}$ ID) analytical column with a He flow rate of $2 \mathrm{ml} \mathrm{min}^{-1}$. PLFA $\delta^{13} \mathrm{C}$ data were corrected for the addition of the methyl group by simple mass balance, and were calibrated by our own internal and external FAME standards. Stable isotope data could be determined for 12 PLFAs in all lakes (see Appendix). Analytical reproducibility was estimated to be $0.6 \%$ or better. Bulk sediment particulate organic carbon (POC) $\delta^{13} \mathrm{C}$ was measured by elemental analyzer-IRMS after removal of inorganic carbon by acidification. A full description of the $\delta^{13} \mathrm{C}$ PLFA and sediment analysis can be found in Boschker et al. (1999, 2005). We also measured $\delta^{13} \mathrm{C}$ in lake DOC by direct injection on a Thermo Isolink LC-IRMS system. Samples for DOC analysis $(1 \mathrm{ml}$ ) were acidified with $25 \mu \mathrm{l}$ of $85 \%$ phosphoric acid and purged with helium gas to remove inorganic carbon shortly before injection onto the LC-IRMS.
When analysing bacterial PLFA as representatives of the heterotrophic bacterial biomass, there is an offset between the total biomass and PLFA (the latter being more ${ }^{13} \mathrm{C}$-depleted) due to fractionation effects during fatty acid synthesis (Boschker et al. 1999, Bouillon \& Boschker 2006). Stable isotopic composition of heterotrophic bacteria was calculated from the isotope data of bacterial i15:0 and a15:0 fatty acids. The results of these PLFAs were combined using an isotope balance as shown by Boschker et al. (1999). The bacterial PLFAs i+a15:0 are depleted in ${ }^{13} \mathrm{C}$ by $-3.7 \pm$ $2.1 \%$ compared to the bacterial substrate (Bouillon \& Boschker 2006). The isotopic composition of the heterotrophic bacterial biomass was therefore calculated from the PLFA ratio as: $\delta^{13} \mathrm{C}_{\text {bact }}=\delta^{13} \mathrm{C}_{\mathrm{i}+\mathrm{a} 15: 0}+3.7$ (\%). The $\delta^{13} \mathrm{C}$ ratios for the main PLFA biomarkers that contain a contribution from methanotrophic bacteria

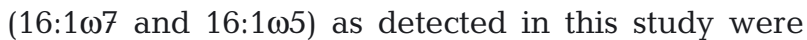
also combined using an isotope balance similarly as for the heterotrophic biomarkers. The 16:1 107 and 16:1 15 PLFA are also found in other bacteria besides Type I methanotrophs, and strongly negative isotopic ratios in these PLFAs indicate a higher contribution from methanotrophic biomass. It should also be noted that the specific Type I methanotrophic biomarkers $16: 1 \omega 6$ and $16: 1 \omega 8$ were not separated by the GCIRMS from the more abundant 16:1 107 , and are therefore included in the $16: 1 \omega 7 \delta^{13} \mathrm{C}$ data.

\section{RESULTS}

The lakes ranged from clear water to humic, with DOC concentrations between 6.8 and $34.9 \mathrm{mg} \mathrm{l}^{-1}$ and TP concentrations between 11.7 and $49.7 \mu \mathrm{g} \mathrm{l}^{-1}$ during summer sampling (Table 1). The highest microbial biomass was found in the profundal sediment of Lake Valloxen, coinciding with the highest TP concentrations in the water. One of the shallowest lakes in this study, Lake Fälaren, with the highest DOC had the highest microbial biomass in the littoral sediment (Table 1). Stable isotope measurements of PLFA were conducted for summer samples of all lakes. In Lötsjön, a lake with intermediate DOC and TP concentrations, both summer and winter stable isotopic data were available. We use this lake to exemplify stable carbon isotope ratios $\left(\delta^{13} \mathrm{C}\right)$ in those PLFAs which we could detect in this study (Fig. 1). The other lakes are displayed in the Appendix. Clearly, $\delta^{13} \mathrm{C}$ signatures were more depleted in some PLFAs than in others (Fig. 1). The isotopic ratios of the most enriched PLFAs were relatively similar and formed a baseline consisting of markers of heterotrophic bacte- 

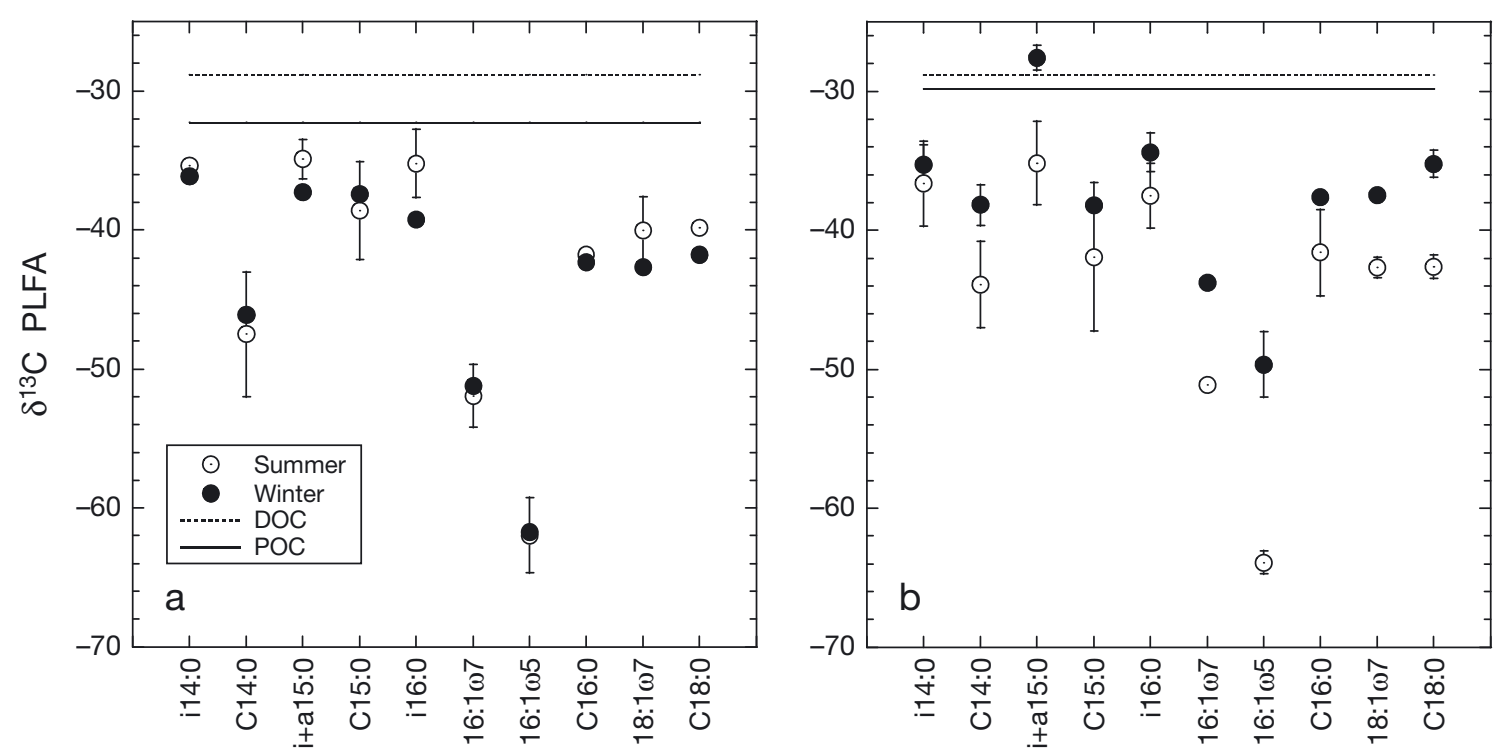

Fig. 1. Stable carbon isotope ratios $\left(\delta^{13} \mathrm{C}\right)$ in phospholipid-derived fatty acids (PLFAs) extracted from the sediment of Lake Lötsjön (low dissolved organic carbon [DOC] lake), Sweden, during winter and summer in (a) profundal and (b) littoral sites. $\delta^{13} \mathrm{C}$ of DOC in the lake was $-28.8 \%$, whereas $\delta^{13} \mathrm{C}$ of sediment particulate organic carbon (POC) ranged between -29.8 and $-32.2 \%$ in the littoral and profundal, respectively

ria at around $-37 \%$, whereas only $16: 1 \omega 7$ and $16: 1 \omega 5$ were clearly depleted, with an isotopic signal varying between -50 and $-65 \%$. In some lakes such as Lake Lötsjön, the 14:0 PLFA was also depleted, but to a lesser extent than the 16-carbon, monounsaturated fatty acids (Fig. 1). At the profundal site, ratios were similar in summer and winter (Fig. 1a), whereas the PLFAs were generally more depleted in summer than in winter in the littoral (Fig. 1b). This was especially

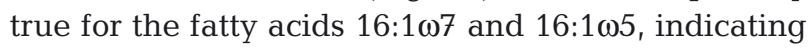
a higher contribution from methanotrophy at the littoral site during the warm season.

\section{Carbon sources of heterotrophic bacteria}

At profundal sites, PLFAs specific for heterotrophic bacteria $\left(\delta^{13} C_{i+a 15: 0}\right)$ were always more depleted in ${ }^{13} \mathrm{C}$ than the terrestrial $\mathrm{C} 3$ plants that are precursors of aquatic allochthonous material $(-27 \%$; Karlsson et al. 2003), whereas they were enriched compared to estimates of autochthonous organic carbon (phytoplankton in the range of -36 to $-47 \%$; Karlsson et al. 2003, Premke et al. 2010) (Fig. 2a,b).

In the littoral, the isotopic signal of heterotrophic bacteria was more enriched than in the profundal (Fig. 2c,d), and hence closer to the heavier isotopic composition of terrestrial material (POC, DOC), benthic algae, or submerged macrophytes $(-25$ to $-32 \%$; Boschker et al. 1999, 2005).

\section{Methanotrophic PLFA signal}

The $\delta^{13} \mathrm{C}$ ratios of fatty acids found in type I methanotrophic bacteria $(16: 1 \omega 7$ and $16: 1 \omega 5)$ ranged from -73 to $-32 \%$ and decreased in most lakes with increasing TP (Fig. 3), i.e. being less depleted in oligotrophic lakes than in more eutrophic ones. This clearly suggests a higher contribution of methanotrophy in eutrophic lakes. The $\delta^{13} \mathrm{C}$ values of the profundal samples varied between -73 and $-45 \%$ and were correlated to TP concentrations $\left(\mathrm{R}^{2}=0.48\right.$ and 0.71 for $16: 1 \omega 7 \mathrm{c}$ and $16: 1 \omega 5$, respectively), while $\delta^{13} \mathrm{C}$ values were more scattered at the littoral sites.

Due to the similar patterns of 16:1 107 (Fig. 3a) and 16:1 $\omega 5$ (Fig. 3b), we estimated a combined $\delta^{13} \mathrm{C}$, as also done for the heterotrophic biomarkers (see 'Materials and methods'). The $\delta^{13} \mathrm{C}$ ratios of heterotrophs (PLFAi+a15:0) and the contribution of methanotrophs (PLFA16:1 $\omega 5+\omega 7$ ) were strongly correlated $\left(R^{2}=0.72\right.$, Fig. 4). This may suggest the indirect use of $\mathrm{CH}_{4}$-derived carbon by heterotrophs, and the same relationship holds for both littoral and profundal sites in all studied lakes.

\section{DISCUSSION}

Carbon isotopic ratios of different bacterial PLFAs, e.g. i14:0, C14:0, i+a15:0, C15:0, and C16:0, were relatively similar, and the most enriched PLFAs formed 

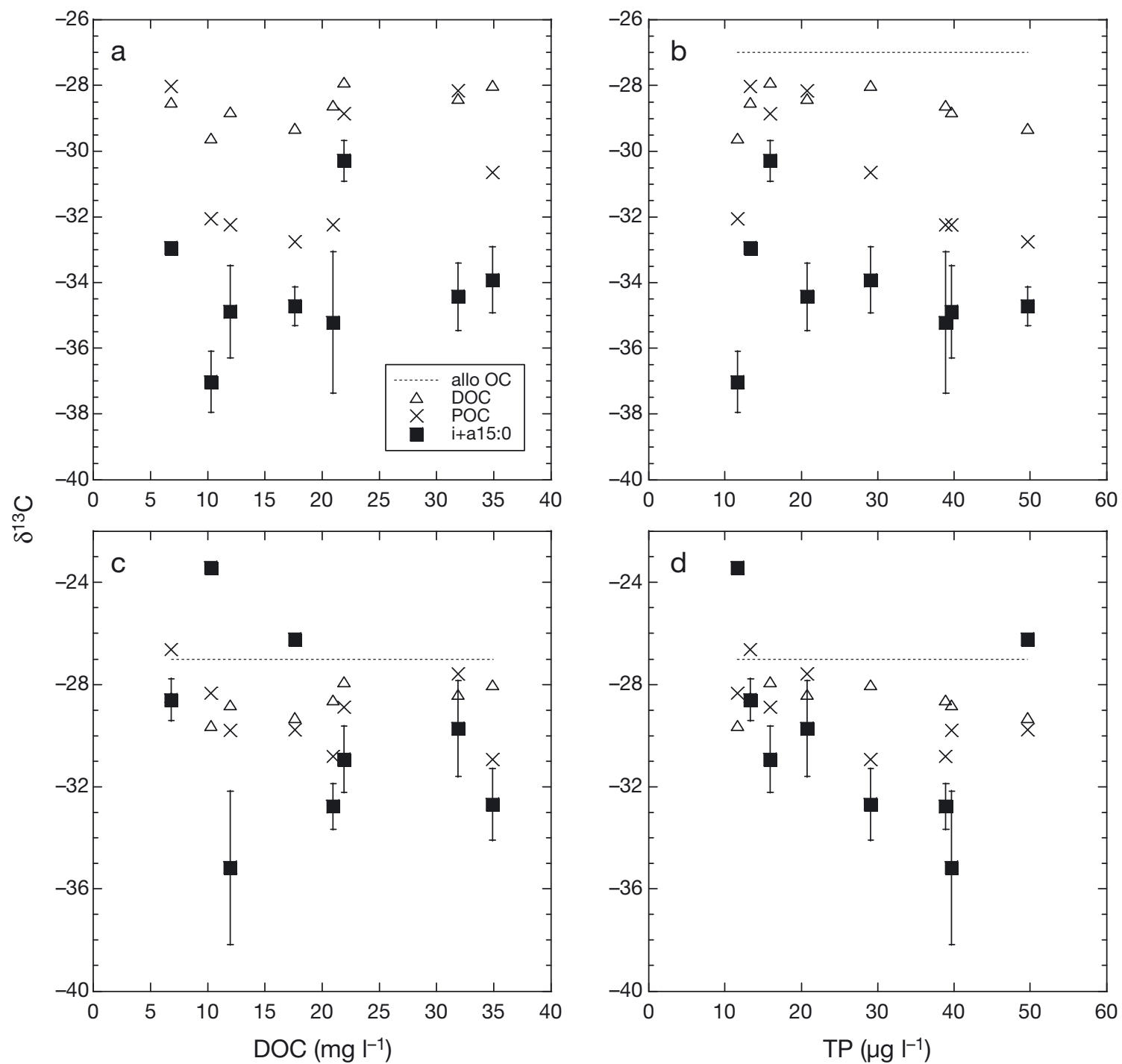

Fig. 2. $\delta^{13} \mathrm{C}$ in PLFAs specific for heterotrophic bacteria (i+a15:0) along a range of $(\mathrm{a}, \mathrm{c})$ dissolved organic carbon (DOC) and $(b, d)$ total phosphorus (TP) concentrations at $(\mathrm{a}, \mathrm{b})$ profundal and $(\mathrm{c}, \mathrm{d})$ littoral sites during summer. The $\delta^{13} \mathrm{C}$ of DOC in the lakes and the $\delta^{13} \mathrm{C}$ of sediment particulate organic carbon (POC) are also plotted. $\delta^{13} \mathrm{C}$ of allochthonous organic carbon (allo OC) in the lakes was assumed to be $-27 \%$

the heterotrophic baseline ranging between -30 and $-40 \%$ (see Appendix). A clearly depleted isotopic signal between -50 and $-70 \%$ was obvious for the monounsaturated fatty acids 16:107 and 16:105 as expected according to previous demonstrations that these contain a contribution from methanotrophic bacteria, more specifically from type I methanotrophs. In our study, type I methanotrophs comprised up to $9 \%$ of the total microbial biomass (Steger et al. 2011), akin to what Sundh et al. (2005) found in similar lakes. The fatty acid 18:1 107 possibly containing a contribution of type II methanotrophs was detected in all lakes, but was not isotopically depleted, suggesting that it was mainly derived from other, non- methanotrophic bacteria. Hence, type I was most likely the dominant group of methanotrophic bacteria in all of these sediments. This finding is in agreement with other studies in sediments of freshwater habitats (Boschker et al. 1998, Costello et al. 2002, Eller et al. 2005, Rahalkar et al. 2009). Boschker et al. (1998) showed the dominance of type I methanotrophs for the first time with $\mathrm{C}^{13}$-methane labeling experiments. Besides the PLFA approach, molecular techniques like slot-blot hybridization (Costello et al. 2002), qPCR (real-time PCR), and fluorescence in situ hybridization (Eller et al. 2005, Rahalkar et al. 2009) support the dominance of type I methanotrophs in freshwater lake sediments. 


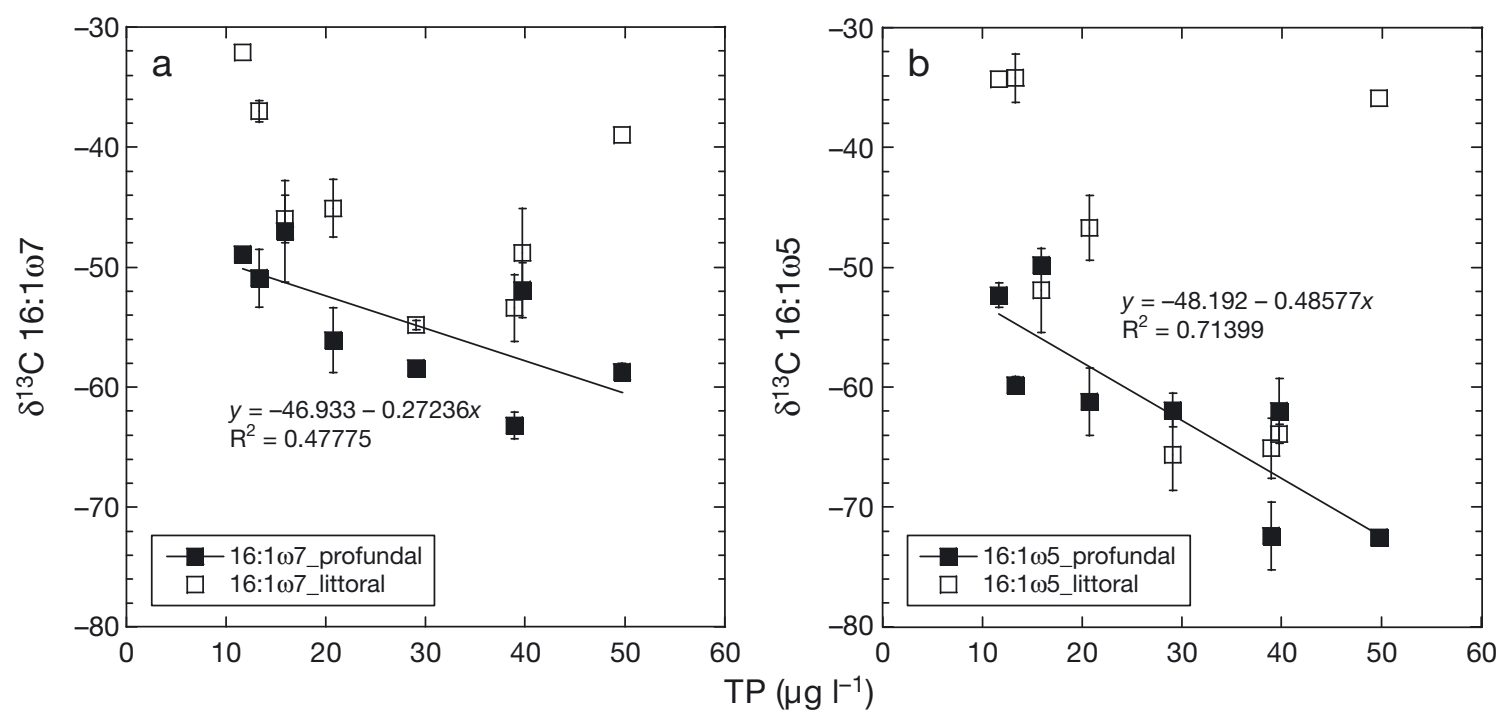

Fig. 3. $\delta^{13} \mathrm{C}$ in PLFAs with high contributions of methanotrophic bacteria (a) 16:1 17 and (b) 16:1 105 as a function of total phosphorus (TP) concentrations in the profundal and littoral zones during summer

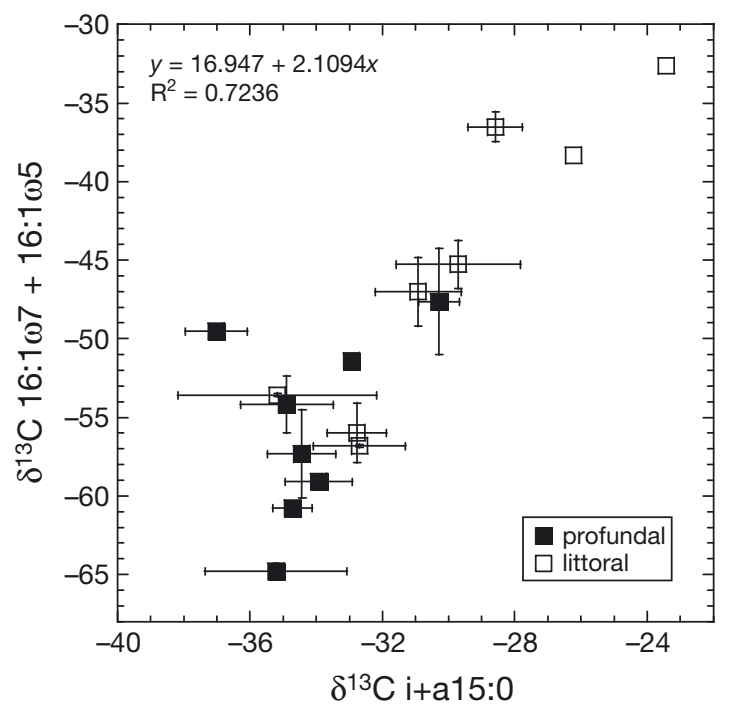

Fig. 4. Relationship between stable carbon isotope ratios in PLFAs in type I methanotrophs $\left(\delta^{13} \mathrm{C}_{16: 1 \omega 7+16: 1 \omega 5}\right)$ and heterotrophs $\left(\delta^{13} \mathrm{C}_{\mathrm{i}+\mathrm{a} 15: 0}\right)$ in 8 boreal lake sediments

In one of the lakes (Lötsjön), we analyzed isotopic composition in both summer and winter. At the littoral site, isotopic signals were more depleted in summer than in winter (Fig. 1b), whereas the profundal varied less between the 2 sampling seasons (Fig. 1a). This may be due to less pronounced seasonal variation in temperature and light at the bottom of the lake. The difference in $\delta^{13} \mathrm{C}$ ratios of summer and winter samples was especially true for fatty acids abundant in type I methanotrophs $(16: 1 \omega 5+\omega 7)$, indicating more methanotrophy during the warm season at the littoral site.
In general, the $\delta^{13} \mathrm{C}$ values of all analyzed PLFAs were more enriched in the littoral than at the profundal sites (Fig. 1 and Appendix), suggesting the use of different organic matter by the organisms (Abraham et al. 1998, Boschker et al. 1999). This is in line with the results from benthic animals (Premke et al. 2010), where higher $\delta^{13} \mathrm{C}$ in littoral zoobenthos was attributed to preferential use of $\delta^{13} \mathrm{C}$-enriched benthic algae in the littoral and $\delta^{13} \mathrm{C}$-depleted phytoplankton and allochthonous organic carbon at the profundal sites.

In the profundal, the $\delta^{13} \mathrm{C}$ signal of PLFAs specific for heterotrophic bacteria (Fig. 2) was always more depleted $(-37$ to $-30 \%$ ) compared to the signal of allochthonous organic carbon $(-27 \%$; Fig. $2 \mathrm{a}, \mathrm{b})$. This suggests that autochthonous material (phytoplankton and its exudates; about -36 to $-47 \%$; Karlsson et al. 2003, Premke et al. 2010), which is isotopically lighter than allochthonous organic carbon, is preferentially used by heterotrophic bacteria in the profundal habitat. In contrast, the $\delta^{13} \mathrm{C}$ ratios of heterotrophs were more enriched in the littoral than in the profundal samples (Fig. 2c,d). In some lakes, the signal was even more enriched than the signal of allochthonous organic carbon. This corresponds to a contribution of benthic microalgae and/or submerged macrophytes, which carry more enriched signals in isotopic composition. The isotopic ratio of benthic algae in Swedish lakes has previously been reported at -24 and $-20 \%$ (Karlsson \& Byström 2005, Premke et al. 2010). Possibly, benthic algae are a dominant carbon source in lakes with highly enriched isotopic signals (Fig. 2c,d). The concentrations of DOC and the $\delta^{13} \mathrm{C}_{\mathrm{i}+\mathrm{a} 15: 0}$ ratios (Fig. 2a,c) were not correlated, 
which is in line with results of a previous study where microbial biomass depended more on TP but not on DOC concentrations (Steger et al. 2011). In general, the heterotrophic bacteria $\left(\delta^{13} \mathrm{C}_{\mathrm{i}+\mathrm{a} 15: 0}\right)$ tended to be negatively related to TP concentrations, i.e. with higher amounts of phytoplankton in the lakes, the signals got more depleted towards a ratio of $-40 \%$ (Fig. 2b,d), implying that heterotrophic bacteria might rely more on autochthonous material in eutrophic lakes. However, in the lake with the highest TP concentration in the water column, the littoral signal was heavily enriched (Fig. 2d). One explanation for this was most probably the littoral sampling close to the emergent vegetation belt, where Phragmites was the dominant taxon with an isotopic signal between -26 and $-28 \%$ o (Boschker et al.1999). This may explain a rather enriched signal in the isotopic composition of heterotrophic biomarkers at this site. However, the utilization of autochthonous versus allochthonous sources should be evaluated with care, as methane oxidation plays an important role in the carbon cycle of lake sediments and also leads to depleted carbon isotopic signals in the food web.

The $\delta^{13} \mathrm{C}$ ratios of both fatty acids abundant in type

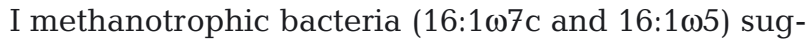
gest higher contribution of methane-derived carbon in more eutrophic lakes compared to oligotrophic lakes (Fig. 3). This was especially true for the profundal sediments, where $\delta^{13} \mathrm{C}$ methanotrophic fatty acids and TP concentrations were strongly correlated. This correlation was not equally obvious in the littoral sediments, since a few lakes showed more enriched signals for both methantrophic fatty acids of around $-35 \%$, which may indicate a masking effect by the influence of benthic algae. The littoral habitat is more variable than the profundal. For example, light conditions at the littoral sediment surface are strongly constrained by light attenuation by colored DOC in the water column, i.e. colored allochthonous organic matter in high-DOC lakes reduces primary production by benthic algae, which may be highly abundant at the littoral sediment surfaces of clearwater lakes with low concentrations of colored DOC (Karlsson et al. 2009).

Since patterns in the $\delta^{13} \mathrm{C}$ ratios of both $16: 1 \omega 7$ (Fig. 3a) and 16:165 (Fig. 3b) were similar, we applied a combined isotope balance $\left(\delta^{13} \mathrm{C}_{16: 1 \omega 5+\omega 7}\right)$ similarly as for the heterotrophic biomarkers $\left(\delta^{13} \mathrm{C}_{\mathrm{i}+\mathrm{a} 15: 0}\right)$. The PLFA $\delta^{13} \mathrm{C}$ ratios calculated in this way for methanotrophic bacteria and total heterotrophic bacteria were strongly correlated (Fig. 4), which may imply an indirect use of $\mathrm{CH}_{4}$-derived carbon by heterotrophs, for instance through the utilization of methano- trophic biomass or detritus. This relationship holds for both littoral and profundal sites in all lakes. The correlation between $\delta^{13} \mathrm{C}$ ratios of heterotrophic bacterial biomarkers and POC was much lower (profundal sediments $R^{2}=0.4$ and littoral sediments $R^{2}=0.3$ ), suggesting that the variation in the isotopic composition of the POC can only partially explain the variation in heterotrophic bacterial biomarkers. The heterotrophic biomarkers i+a15:0 are mostly absent or occur in low abundance ( $2 \%$ of the total PLFA or less) in methanotrophic bacteria that have been screened for PLFA composition (Bodelier et al. 2009). The direct contribution of methanotrophic PLFA to the heterotrophic markers is therefore most likely very minor and cannot explain the strong relationship in isotopic composition as found in Fig. 4. Another explanation could be that the isotopic signals of both the heterotrophic bacteria and the methane produced in the sediment depend on the isotopic composition of the sediment organic matter. However, this seems less likely, as the isotopic variation in methanotrophic markers was much larger than in heterotrophic bacteria (Fig. 4). In addition, phytoplankton $\delta^{13} \mathrm{C}$ ratios tend to be highly variable in lakes but typically do not correlate negatively with TP or phytoplankton biomass (de Kluijver et al. 2014), as found for the methanotrophic biomarkers in our study. It has been repeatedly shown that methane-derived carbon can be important in zoobenthic food webs (Grey et al. 2004, Jones \& Grey 2011), and our results may indicate that the same holds true for heterotrophic bacteria in sediments of freshwater lakes. These results strongly suggest that the isotopic signal in heterotrophic bacteria (i+a15:0) should be used with care to indicate whether terrestrial inputs or local primary production are driving carbon mineralization in lake sediments, as it may be masked by the strongly depleted methanotrophic signal.

In conclusion, we demonstrate that methane may be an important carbon source for sediment bacteria in a range of boreal lakes with varying productivity and influence of allochthonous organic matter. Moreover, in profundal sediments, the ${ }^{13} \mathrm{C}$ of PLFAs indicative of heterotrophic bacteria was more depleted than in the littoral, suggesting different carbon sources, possibly with phytoplankton being a more important carbon source in the profundal, and the utilization of benthic algae, submersed macrophytes, and terrestrial matter in the littoral. However, the isotopic signal in heterotrophic bacteria was apparently influenced by the strongly depleted methanotrophic signal. Therefore, methane-derived carbon may also indirectly be an important carbon source for the non- 
methanotrophic heterotrophic bacteria, thereby masking the terrestrial input and local primary production signals due to indirect feeding on isotopically depleted methane.

Acknowledgements. We thank Jan Johansson for sample analyses and technical support. The Department of Microbiology at the Swedish University of Agricultural Sciences (SLU) is acknowledged for kindly providing access to the GC-MS equipment. This study was funded by the Swedish Research Council for Environment, Agriculture Sciences, and Spatial Planning (FORMAS) and was part of the research environment 'Lake Ecosystem Response to Environmental Change' (LEREC).

\section{LITERATURE CITED}

Abraham WR, Hesse C, Pelz O (1998) Ratios of carbon isotopes in microbial lipids as an indicator of substrate usage. Appl Environ Microbiol 64:4202-4209

Bastviken D, Ejlertsson J, Sundh I, Tranvik L (2003) Methane as a source of carbon and energy for lake pelagic food webs. Ecology 84:969-981

Bastviken D, Tranvik LJ, Downing JA, Crill PM, EnrichPrast A (2011) Freshwater methane emissions offset the continental carbon sink. Science 331:50

Battin TJ, Luyssaert S, Kaplan LA, Aufdenkampe AK, Richter A, Tranvik LJ (2009) The boundless carbon cycle. Nat Geosci 2:598-600

Bodelier PLE, Gillisen MJB, Hordijk K, Damste JSS, Rijpstra WIC, Geenevasen JAJ, Dunfield PF (2009) A reanalysis of phospholipid fatty acids as ecological biomarkers for methanotrophic bacteria. ISME J 3:606-617

Boschker HTS, Nold SC, Wellsbury P, Bos D and others (1998) Direct linking of microbial populations to specific biogeochemical processes by ${ }^{13} \mathrm{C}$-labelling of biomarkers. Nature 392:801-805

- Boschker HTS, de Brouwer JFC, Cappenberg TE (1999) The contribution of macrophyte-derived organic matter to microbial biomass in salt-marsh sediments: stable carbon isotope analysis of microbial biomarkers. Limnol Oceanogr 44:309-319

- Boschker HTS, Kromkamp JC, Middelburg JJ (2005) Biomarker and carbon isotopic constraints on bacterial and algal community structure and functioning in a turbid, tidal estuary. Limnol Oceanogr 50:70-80

Bouillon S, Boschker HTS (2006) Bacterial carbon sources in coastal sediments: a cross-system analysis based on stable isotope data of biomarkers. Biogeosciences 3:175-185

Bowman JP, Skerratt JH, Nichols PD, Sly LI (1991) Phospholipid fatty acid and lipopolysaccharide fatty acid signature lipids in methane-utilizing bacteria. FEMS Microbiol Ecol 85:15-22

Cole JJ, Caraco NF, Kling GW, Kratz TK (1994) Carbondioxide supersaturation in the surface waters of lakes. Science 265:1568-1570

> Cole JJ, Pace ML, Carpenter SR, Kitchell JF (2000) Persistence of net heterotrophy in lakes during nutrient addition and food web manipulations. Limnol Oceanogr 45: 1718-1730

Costello AM, Auman AJ, Macalady JL, Scow KM, Lidstrom ME (2002) Estimation of methanotroph abundance in a freshwater lake sediment. Environ Microbiol 4:443-450 de Kluijver A, Schoon PL, Downing JA, Schouten S, Middelburg JJ (2014) Stable carbon isotope biogeochemistry of lakes along a trophic gradient. Biogeosciences 11: 6265-6276

del Giorgio PA, Cole JJ, Caraco NF, Peters RH (1999) Linking planktonic biomass and metabolism to net gas fluxes in northern temperate lakes. Ecology 80:1422-1431

Eller G, Deines P, Grey J, Richnow HH, Kruger M (2005) Methane cycling in lake sediments and its influence on chironomid larval $\delta^{13} \mathrm{C}$. FEMS Microbiol Ecol 54:339-350

Frostegård A, Tunlid A, Bååth E (1991) Microbial biomass measured as total lipid phosphate in soils of different organic content. J Microbiol Methods 14:151-163

> Grey J, Kelly A, Ward S, Sommerwerk N, Jones RI (2004) Seasonal changes in the stable isotope values of lakedwelling chironomid larvae in relation to feeding and life cycle variability. Freshw Biol 49:681-689

- Hanson RS, Hanson TE (1996) Methanotrophic bacteria. Microbiol Rev 60:439-471

Jansson M, Persson L, De Roos AM, Jones RI, Tranvik LJ (2007) Terrestrial carbon and intraspecific size-variation shape lake ecosystems. Trends Ecol Evol 22:316-322

Jones RI (1992) The influence of humic substances on lacustrine planktonic food-chains. Hydrobiologia 229:73-91

Jones RI, Grey J (2004) Stable isotope analysis of chironomid larvae from some Finnish forest lakes indicates dietary contribution from biogenic methane. Boreal Environ Res 9:17-23

Jones RI, Grey J (2011) Biogenic methane in freshwater food webs. Freshw Biol 56:213-229

> Jonsson A, Karlsson J, Jansson M (2003) Sources of carbon dioxide supersaturation in clearwater and humic lakes in northern Sweden. Ecosystems 6:224-235

Karlsson J, Byström P (2005) Littoral energy mobilization dominates energy supply for top consumers in subarctic lakes. Limnol Oceanogr 50:538-543

Karlsson J, Jonsson A, Meili M, Jansson M (2003) Control of zooplankton dependence on allochthonous organic carbon in humic and clear-water lakes in northern Sweden. Limnol Oceanogr 48:269-276

Karlsson J, Bystrom P, Ask J, Ask P, Persson L, Jansson M (2009) Light limitation of nutrient-poor lake ecosystems. Nature 460:506-509

> Kiyashko SI, Narita T, Wada E (2001) Contribution of methanotrophs to freshwater macroinvertebrates: evidence from stable isotope ratios. Aquat Microb Ecol 24: 203-207

Kritzberg ES, Cole JJ, Pace ML, Graneli W, Bade DL (2004) Autochthonous versus allochthonous carbon sources of bacteria: results from whole-lake ${ }^{13} \mathrm{C}$ addition experiments. Limnol Oceanogr 49:588-596

> Murphy J, Riley JP (1962) A modified single solution method for the determination of phosphate in natural waters. Anal Chim Acta 27:31-36

- Pace ML, Cole JJ, Carpenter SR, Kitchell JF and others (2004) Whole-lake carbon-13 additions reveal terrestrial support of aquatic food webs. Nature 427:240-243

Premke K, Karlsson J, Steger K, Gudasz C, Von Wachenfeldt E, Tranvik LJ (2010) Stable isotope analysis of benthic fauna and their food sources in boreal lakes. J N Am Benthol Soc 29:1339-1348

> Rahalkar M, Deutzmann J, Schink B, Bussmann I (2009) Abundance and activity of methanotrophic bacteria in littoral and profundal sediments of Lake Constance 
(Germany). Appl Environ Microbiol 75:119-126

Sobek S, Algesten G, Bergstrom AK, Jansson M, Tranvik LJ (2003) The catchment and climate regulation of $\mathrm{pCO}_{2}$ in boreal lakes. Glob Change Biol 9:630-641

Steger K, Jarvis Å, Smårs S, Sundh I (2003) Comparison of signature lipid methods to determine microbial community structure in compost. J Microbiol Methods 55: 371-382

Steger K, Premke K, Gudasz C, Sundh I, Tranvik LJ (2011) Microbial biomass and community composition in boreal lake sediments. Limnol Oceanogr 56:725-733

Sundh I, Bastviken D, Tranvik LJ (2005) Abundance, activity, and community structure of pelagic methane-oxidizing bacteria in temperate lakes. Appl Environ Microbiol 71: $6746-6752$
Tranvik LJ (1988) Availability of dissolved organic carbon for planktonic bacteria in oligotrophic lakes of differing humic content. Microb Ecol 16:311-322

Tunlid A, White DC (1992) Biochemical analysis of biomass, community structure, nutritional status, and metabolic activity of microbial communities in soil. In: Stotzky G, Bollag JM (eds) Soil biochemistry, Book 7. Marcel Dekker, New York, NY, p 229-262

von Wachenfeldt E, Tranvik LJ (2008) Sedimentation in boreal lakes - the role of flocculation of allochthonous dissolved organic matter in the water column. Ecosystems 11:803-814

Whiticar MJ (1999) Carbon and hydrogen isotope systematics of bacterial formation and oxidation of methane. Chem Geol 161:291-314

Appendix. Stable carbon isotope ratios $\left(\delta^{13} \mathrm{C}\right)$ in PLFAs extracted from the sediments of 8 boreal lakes in Sweden (A: Ljustjärn; B: Lilla Sångaren; C: Lötsjön; D: Valloxen; E: Oppsveten; F: Strandsjön; G: Svarttjärn; H: Fälaren) in profundal (1) and littoral (2) sites. Values are in $\%$ o \pm SD. ND: not detected

\begin{tabular}{|c|c|c|c|c|c|c|c|c|c|c|c|c|}
\hline Lake & i14:0 & C14:0 & i15:0 & a15:0 & C15:0 & C16:0 & $16: 1 \omega 6 / 7 / 8$ & $16: 1 \omega 7 t$ & $16: 1 \omega 5$ & C16:0 & $18: 1 \omega 7$ & C18:0 \\
\hline A1 & $-38.0 \pm 1.7$ & $-41.6 \pm 2.6$ & $-42.0 \pm 1.8$ & $-40.5 \pm 0.5$ & $-34.6 \pm 1.7$ & $-39.2 \pm 1.0$ & $-48.9 \pm 0.3$ & $-52.9 \pm 1.2$ & $-52.3 \pm 1.0$ & $-42.4 \pm 2.5$ & $-35.5 \pm 3.0$ & $-35.8 \pm 1.1$ \\
\hline A2 & -25.2 & -27.6 & -26.2 & -28.5 & -26.0 & -27.3 & -32.1 & ND & -34.3 & -31.2 & -32.9 & -28.6 \\
\hline B1 & $-35.8 \pm 3.1$ & $-37.9 \pm 1.5$ & $-35.7 \pm 0.6$ & $-37.7 \pm 0.5$ & $-38.5 \pm 0.0$ & $-35.7 \pm 0.5$ & $-50.9 \pm 2.4$ & $-55.0 \pm 0.5$ & $-59.8 \pm 0.7$ & $-39.1 \pm 1.0$ & $-40.2 \pm 0.0$ & $-34.8 \pm 1.1$ \\
\hline B2 & $-28.7 \pm 3.2$ & $-33.7 \pm 3.0$ & $-30.8 \pm 1.2$ & $-33.5 \pm 0.7$ & $-32.9 \pm 0.4$ & $-32.0 \pm 0.6$ & $-37.0 \pm 0.9$ & $-34.4 \pm 3.3$ & $-34.2 \pm 2.0$ & $-34.5 \pm 1.9$ & $-31.8 \pm 1.7$ & $-32.2 \pm 1.1$ \\
\hline C1 & $-35.4 \pm 0.0$ & $-47.5 \pm 4.5$ & $-40.6 \pm 0.5$ & $-37.9 \pm 2.4$ & $-38.6 \pm 3.5$ & $-35.2 \pm 2.4$ & $-51.9 \pm 2.3$ & $-55.8 \pm 4.5$ & $-62.0 \pm 2.7$ & $-41.8 \pm 0.5$ & $-40.0 \pm 2.4$ & $-39.8 \pm 0.4$ \\
\hline $\mathrm{C} 2$ & $-36.6 \pm 3.1$ & $-43.9 \pm 3.1$ & $-40.5 \pm 0.8$ & $-38.5 \pm 4.1$ & $-41.9 \pm 5.3$ & $-37.5 \pm 2.3$ & $-51.1 \pm 0.4$ & $-55.8 \pm 0.3$ & $-63.9 \pm 0.8$ & $-41.6 \pm 3.1$ & $-42.7 \pm 0.7$ & $-42.6 \pm 0.8$ \\
\hline D1 & $-36.8 \pm 0.9$ & $-50.1 \pm 0.7$ & $-39.4 \pm 0.9$ & $-38.5 \pm 0.5$ & $-45.3 \pm 0.4$ & $-39.8 \pm 0.2$ & $-58.7 \pm 0.7$ & $-69.0 \pm 0.6$ & $-72.5 \pm 0.2$ & $-46.7 \pm 0.2$ & $-44.3 \pm 0.2$ & $-41.6 \pm 0.6$ \\
\hline D2 & -31.0 & -30.8 & -30.1 & -30.3 & -31.7 & -29.0 & -39.0 & -40.0 & -35.9 & -33.4 & -32.6 & -30.7 \\
\hline E1 & $-32.6 \pm 0.6$ & $-35.6 \pm 1.4$ & $-32.9 \pm 0.1$ & $-35.2 \pm 0.9$ & $-36.2 \pm 3.0$ & $-33.8 \pm 1.5$ & $-47.0 \pm 4.2$ & $-46.6 \pm 1.6$ & $-49.8 \pm 0.3$ & $-36.3 \pm 0.6$ & $-39.0 \pm 1.6$ & $-34.2 \pm 1.4$ \\
\hline E2 & $-32.3 \pm 3.4$ & $-36.7 \pm 5.2$ & $-33.3 \pm 2.3$ & $-34.6 \pm 2.6$ & $-37.4 \pm 0.0$ & $-35.1 \pm 1.2$ & $-46.0 \pm 2.0$ & $-49.1 \pm 0.3$ & $-51.9 \pm 3.5$ & $-37.4 \pm 2.3$ & $-39.3 \pm 2.1$ & $-34.0 \pm 3.3$ \\
\hline F1 & $-38.3 \pm 2.6$ & $-51.2 \pm 3.9$ & $-38.6 \pm 2.4$ & $-39.6 \pm 2.0$ & $-46.9 \pm 3.6$ & $-40.5 \pm 2.0$ & $-63.2 \pm 1.1$ & $-68.7 \pm 1.2$ & $-72.4 \pm 2.8$ & $-51.2 \pm 2.6$ & $-45.0 \pm 0.8$ & $-41.1 \pm 3.4$ \\
\hline F2 & $-34.8 \pm 0.0$ & $-47.4 \pm 1.5$ & $-36.0 \pm 0.2$ & $-37.3 \pm 1.6$ & $-42.5 \pm 2.0$ & $-36.5 \pm 0.9$ & $-53.4 \pm 2.8$ & $-59.2 \pm 0.4$ & $-65.1 \pm 2.5$ & $-41.9 \pm 0.8$ & $-39.1 \pm 0.5$ & $-37.6 \pm 1.7$ \\
\hline G1 & $-36.6 \pm 1.1$ & $-41.3 \pm 0.7$ & $-35.8 \pm 0.9$ & $-40.3 \pm 1.3$ & $-37.9 \pm 0.9$ & $-34.4 \pm 2.0$ & $-56.1 \pm 2.7$ & $-59.8 \pm 0.6$ & $-61.2 \pm 2.8$ & $-40.1 \pm 0.3$ & $-38.0 \pm 0.1$ & $-33.4 \pm 1.1$ \\
\hline $\mathrm{G} 2$ & $-29.4 \pm 2.6$ & $-35.7 \pm 2.9$ & $-33.3 \pm 2.6$ & $-34.0 \pm 1.4$ & $-35.2 \pm 3.3$ & $-34.7 \pm 0.7$ & $-45.1 \pm 2.4$ & $-47.9 \pm 0.5$ & $-46.7 \pm 2.7$ & $-37.1 \pm 0.6$ & $-38.2 \pm 2.2$ & $-35.3 \pm 2.6$ \\
\hline H1 & $-34.0 \pm 1.4$ & $-49.0 \pm 2.4$ & $-37.1 \pm 0.9$ & $-38.5 \pm 1.1$ & $-43.4 \pm 2.6$ & $-38.3 \pm 0.8$ & $-58.4 \pm 0.1$ & $-61.6 \pm 2.2$ & $-61.9 \pm 1.4$ & $-50.5 \pm 2.6$ & $-43.3 \pm 0.3$ & $-39.6 \pm 1.4$ \\
\hline $\mathrm{H} 2$ & $-35.2 \pm 0.5$ & $-48.2 \pm 2.5$ & $-36.4 \pm 1.4$ & $-36.9 \pm 1.4$ & $-42.9 \pm 1.4$ & $-37.9 \pm 1.3$ & $-54.8 \pm 0.4$ & $-59.5 \pm 1.0$ & $-65.6 \pm 3.0$ & $-45.1 \pm 1.5$ & $-38.8 \pm 2.2$ & $-37.4 \pm 2.7$ \\
\hline
\end{tabular}

Editorial responsibility: Tom Fenchel, Helsingør, Denmark
Submitted: January 5, 2015; Accepted: July 15, 2015

Proofs received from author(s): August 12, 2015 